\title{
TELL SABI ABYAD, SYRIA: DATING OF NEOLITHIC CEMETERIES
}

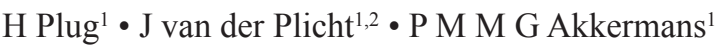

ABSTRACT. Late Neolithic graves excavated at Tell Sabi Abyad, Syria, have been dated by radiocarbon. This series of 46 human bone dates represents a sequence of cemeteries that is analyzed by Bayesian methodology. The dates show continuous use of the northeastern slope of the mound as a burial ground throughout the Initial Pottery Neolithic to the Halaf period.

\section{INTRODUCTION}

Excavations undertaken by Leiden University during the past 25 yr have revealed an unique, continuous sequence of 7th and early 6th millennium occupation layers at Tell Sabi Abyad in northern Syria. Only recently has one of the largest Late Neolithic cemeteries in the Near East known to date come to light. This cemetery yielded hundreds of graves of men, women, and children. A pilot study of 46 skeletal samples has provided a precisely dated sequence of graves, using detailed analysis of the stratigraphy and Bayesian statistics. The resulting chronology enables us to exactly pinpoint patterns in mortuary practices at Tell Sabi Abyad and to define the timing and pace of the changes and innovations in these funerary customs. This makes the cemetery at Tell Sabi Abyad one of the best-dated prehistoric cemeteries in the Near East, with great potential for comparative purposes. This article will focus on the dating of the graves.

\section{EXCAVATIONS AT TELL SABI ABYAD}

Tell Sabi Abyad is located in the Balikh Valley, about $30 \mathrm{~km}$ south of the Syro-Turkish border (Figure 1). The site of Tell Sabi Abyad consists of a group of four small prehistoric mounds, numbered Tell Sabi Abyad I to IV. The mounds are located in a roughly linear north-south orientation at a distance of, at most, a few hundred meters from each other. Excavations have been carried out at three of these mounds: Sabi Abyad I, II, and III. The largest of these mounds, Tell Sabi Abyad I, is about 5 ha in size. It rises $6 \mathrm{~m}$ above the surrounding plain, and its earliest depositions occur at a depth of $4 \mathrm{~m}$ below the modern field level (Akkermans 2008).

The excavations in the northwestern area of Tell Sabi Abyad I (henceforth simply Tell Sabi Abyad), termed Operation III, have revealed a highly complex history of settlement, consisting of four successive phases of deposition: Sequence A ( 7100-6200 BC), Sequence B ( 6200-5900 BC), Sequence C ( $\sim 5900-5800 \mathrm{BC})$, and Sequence D ( 5700-5500 BC). The earliest stratigraphic phase (Sequence A) starts during the Initial Pottery Neolithic (7000-6700 BC) and continues through the Early Pottery Neolithic into the early stages of the Pre-Halaf Pottery stage (until $\sim 6200$ BC; see Nieuwenhuyse et al. 2010 for an explanation of the terminology). Sequence B continues after $\sim 6200$ BC (Pre-Halaf and Transitional periods), followed by deposits dated to the Early Halaf (Sequence C) and the Middle Halaf (Sequence D) periods (van der Plicht et al. 2011). A schematic drawing of the site indicating the various stratigraphic phases is given in Figure 2.

The chronology for the occupation sequences at Tell Sabi Abyad was established during an extensive ${ }^{14} \mathrm{C}$ dating program, which aimed to investigate the possible contemporaneity of a series of cultural changes at the site $\sim 6200 \mathrm{BC}$, with the "8.2ka climate event," a period of rapid climate change. Altogether, $145{ }^{14} \mathrm{C}$ dates were analyzed by Bayesian statistics, establishing the best-dated chronology for a Late Neolithic site in the Near East thus far (van der Plicht et al. 2011).

1. Faculty of Archaeology, Leiden University, Leiden, Netherlands.

2. Center for Isotope Research, Groningen University, Groningen, Netherlands. Corresponding author.

Email: J.van.der.Plicht@rug.nl.

Proceedings of the Radiocarbon and Archaeology 7th International Symposium

Ghent, Belgium, April 2013 | Edited by Mark Van Strydonck, Philippe Crombé, and Guy De Mulder

(C) 2014 by the Arizona Board of Regents on behalf of the University of Arizona 


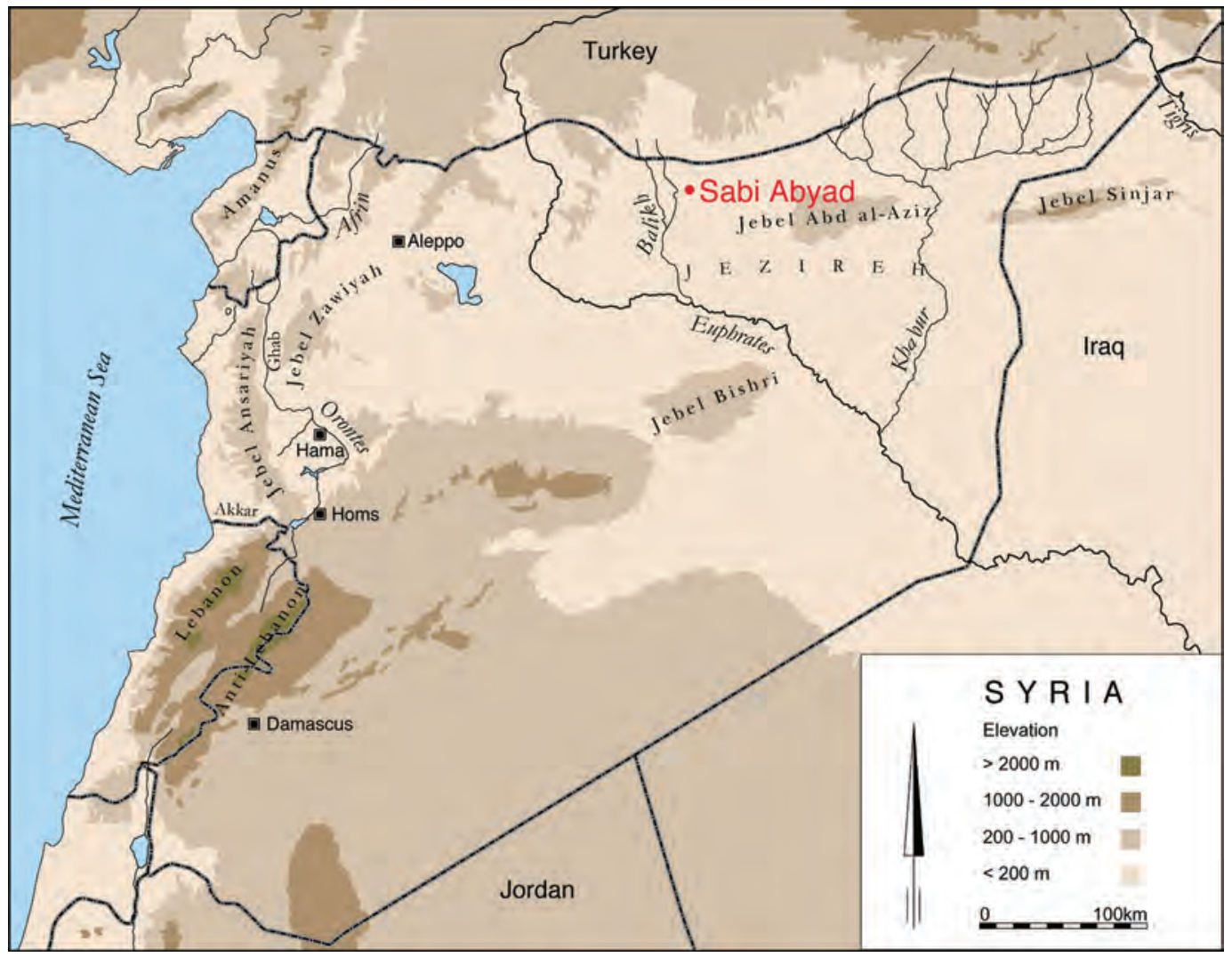

Figure 1 The location of Tell Sabi Abyad in northern Syria

\section{LATE NEOLITHIC GRAVES OF TELL SABI ABYAD}

Until recently, cemeteries were scarce in the archaeological record of the 7th to 6th millennium in northern Mesopotamia. However, recently a number of Late Neolithic graveyards have been discovered, including those at Tell el-Kerkh, northwest Syria; Domuztepe, south-central Turkey; Hakemi Use, southeast Turkey; and Tell Sabi Abyad (Croucher 2012).

The burial ground at Tell Sabi Abyad is, as noted above, one of the largest groups of Late Neolithic cemeteries in the Near East known to date, yielding hundreds of graves of men, women, and chil-

Tell Sabì Abyad: Tell Construction Operation III

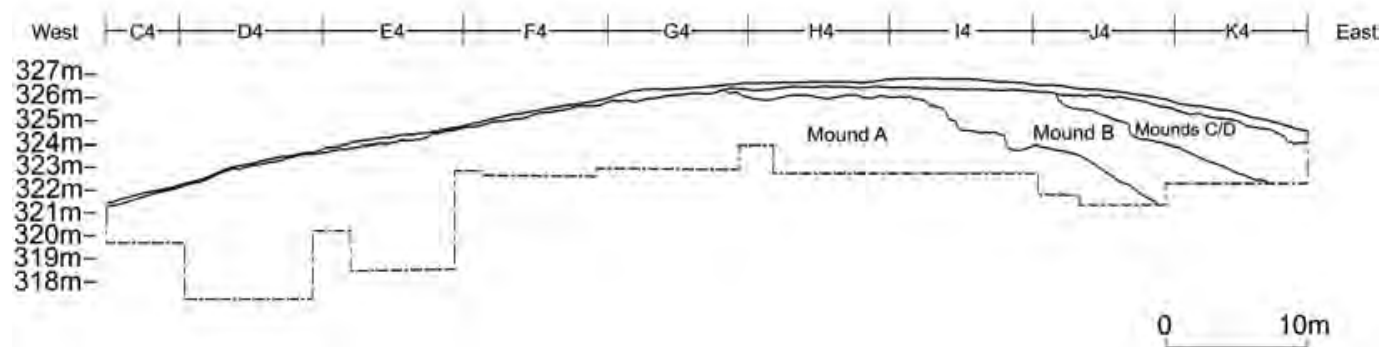

Figure 2 Schematic illustration of the so-called Operation III excavations at Tell Sabi Abyad. Deposition sequences A, B, and $\mathrm{C}$ are discussed in this paper; Sequence $\mathrm{D}$ is not. 
dren. Because of the relative scarcity of information from funerary contexts in Upper Mesopotamia, the burials of Tell Sabi Abyad can potentially provide much useful comparative information regarding life and death of the Late Neolithic people in this region.

Until 2004, only a handful of graves were found at Tell Sabi Abyad. These graves almost exclusively held the remains of children; notably, adults were usually missing (Akkermans 2008). However, in 2005 the first burials were discovered of the almost 200 children and adults found in the cemetery. The cemetery was found in Operation III on the northeastern slope of the highest point of the mound. In 2010, another Late Neolithic cemetery was discovered during excavations on one of the smaller mounds of the site (Tell Sabi Abyad III). Research on these graves, however, has come to a halt due to the recent uprisings in Syria, and therefore cannot be included in this study.

Preliminary investigations have demonstrated a bewildering complexity in the burials found in the cemetery currently under study (Akkermans 2008). The deceased were usually interred in a crouched position on their side in unlined pits usually $\sim 1 \mathrm{~m}$ deep (see Figure 3). Single, primary burials are most common in the cemetery. However, multiple and/or secondary burials also occur, as do primary burials in different positions. The orientation of the burials varies, but the most common orientation is NW-SE and the least frequent N-S. Most graves do not overlap each other, suggesting some sort of visible demarcation of the graves in the past. Pathologies occurred in many different forms, from dental caries to anemia, growth disturbances, and possibly epidemic diseases. Almost half of the deceased were accompanied by grave goods, including pottery, animal bone, personal ornaments and stone and bone tools.

Future research hopes to build on, and expand the current knowledge of, the various physical and cultural aspects of the cemetery. These efforts will include isotopic research $\left({ }^{13} \mathrm{C},{ }^{15} \mathrm{~N}\right.$, and $\mathrm{Sr}$ isotopes), DNA studies, and the analysis of burial custom, grave goods, and health throughout the time of use of the cemetery.

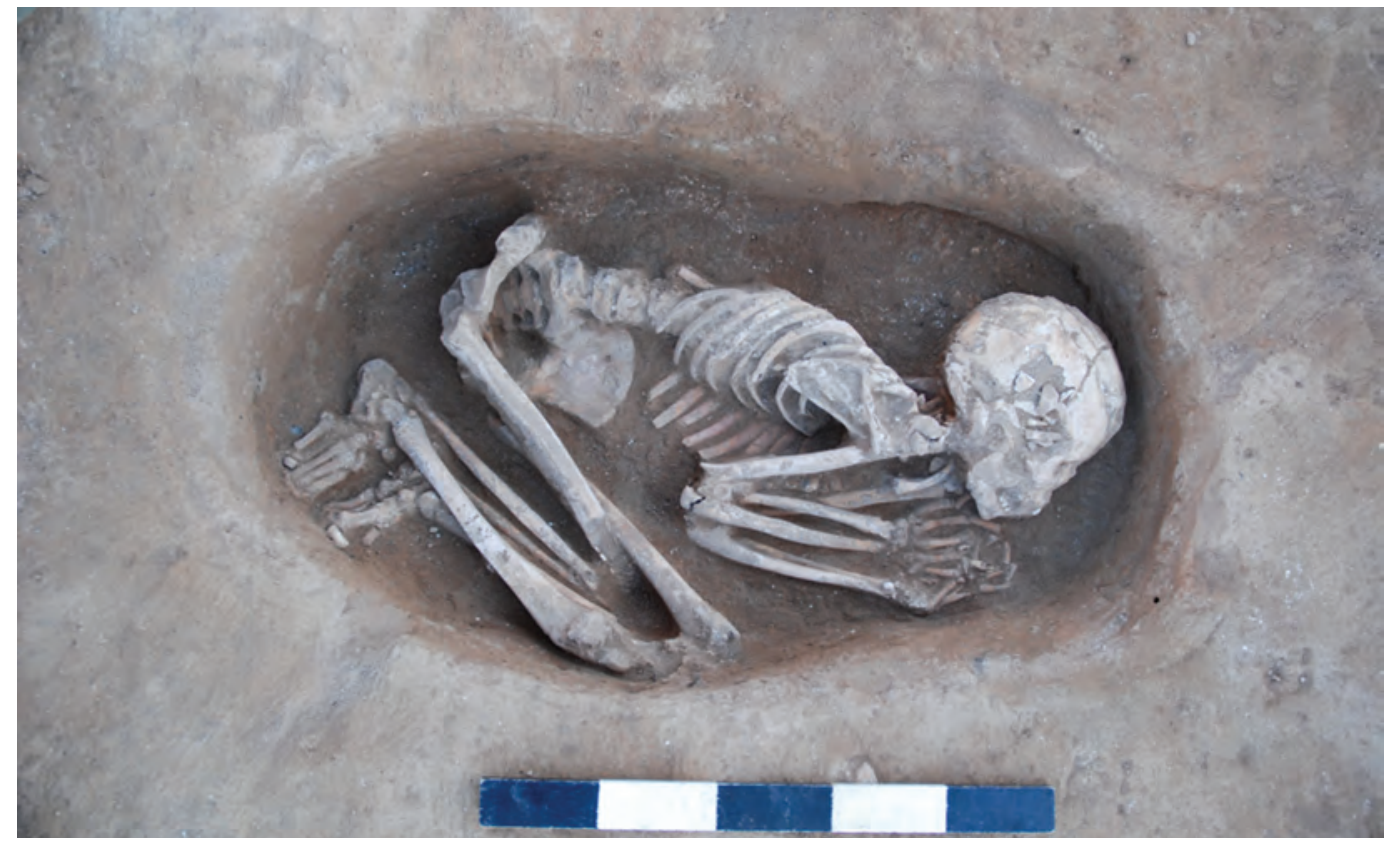

Figure 3 Grave with deceased individual in crouched position 


\section{STRATIGRAPHICAL ANALYSIS: THE CHALLENGES}

Accurate stratigraphical placement of graves at sites with deposition layers such as those at Tell Sabi Abyad can be, to say the least, challenging. Pit fills can be indistinguishable in color and texture from the surrounding soil and are therefore often not immediately recognized while digging, resulting in the loss of the exact original upper height of the burial pit. Additionally, original pit depth may vary significantly; burial pits from as shallow as $50 \mathrm{~cm}$ to as deep as $1.5 \mathrm{~m}$ have been witnessed at the site. The stratigraphical position of graves in open areas and further away from the section walls may therefore ultimately include a certain degree of uncertainty.

In the case of the Late Neolithic burial ground of Tell Sabi Abyad, the placement of the graves is often further complicated by erosion and ancient leveling activities, sometimes removing the greatest part of the burial pit. Periods of no deposition of soil layers combined with ongoing funerary use of the area also appear to be an issue, meaning that graves dug into the same layer may differ significantly in time. Therefore, the resulting picture is very complex, requiring detailed analysis of the stratigraphical context of each individual grave. Despite these efforts, it is often impossible to determine the sequence of individual graves, making the grouping into cemeteries the preferential option.

In certain cases, it was necessary to engage in an iterative process using all data available, including stratigraphical context, pottery types within a grave pit, comparison with nearby graves, and, in the few worst cases, estimation of pit depth and comparison of radiocarbon dates with those taken from surrounding graves. We are aware that the use of the ${ }^{14} \mathrm{C}$ dates in stratigraphical analysis prior to Bayesian analysis can be a tricky undertaking, with the danger of engaging in circular reasoning. However, in a small few cases, which will be elaborated below, we believe that including ${ }^{14} \mathrm{C}$ dates was not only our sole option, but also completely justifiable. In any case, the accurate, critical investigation of the context of each of the burials included in this study has always been our foremost priority.

\section{STRATIGRAPHICAL ANALYSIS: THE RESULTS}

This pilot study concentrated on two bordering, $9 \times 9 \mathrm{~m}$ excavation squares, namely J3 and J4 (Figure 4). These squares yielded the highest density of graves (92) representing all periods in the timespan of the cemetery, and have therefore been selected as a starting point in the research of the Late Neolithic burial grounds. The excavation area in which this burial ground was found, known as Operation III, is schematically shown in Figure 4. This plan shows the excavation squares, including $\mathrm{J} 3$ and $\mathrm{J} 4$, which are of relevance here. Of the 92 graves, 85 could successfully be placed in the stratigraphy of the area. Seven burials, five of which had a ${ }^{14} \mathrm{C}$ date, were excluded on the basis of stratigraphical uncertainty.

Initial investigation in the field seemed to indicate three cemeteries separated by time corresponding to the three main Neolithic occupation phases known at the site: sequences A, B, and C. However, the current study has provided new insights into the chronology of the graves. Close examination of the stratigraphic context of each individual grave and the corresponding ${ }^{14} \mathrm{C}$ data has shown that the northeast slope of the mound was more or less continuously used as burial ground, despite the lack of stratigraphic continuation between sequences A to B and B to C. The borders between these deposition phases were usually clearly visible in the field and in the sections, and are therefore still extremely useful as points of orientation during the stratigraphic placement of the burials.

Even though the northeast slope seems to have some ritual or ideological significance (as confirmed by a similar location of the graves on Tell Sabi Abyad III), this part of the site is not exclusively reserved for the dead, apparent by the presence of domestic architecture. Most graves are not as- 


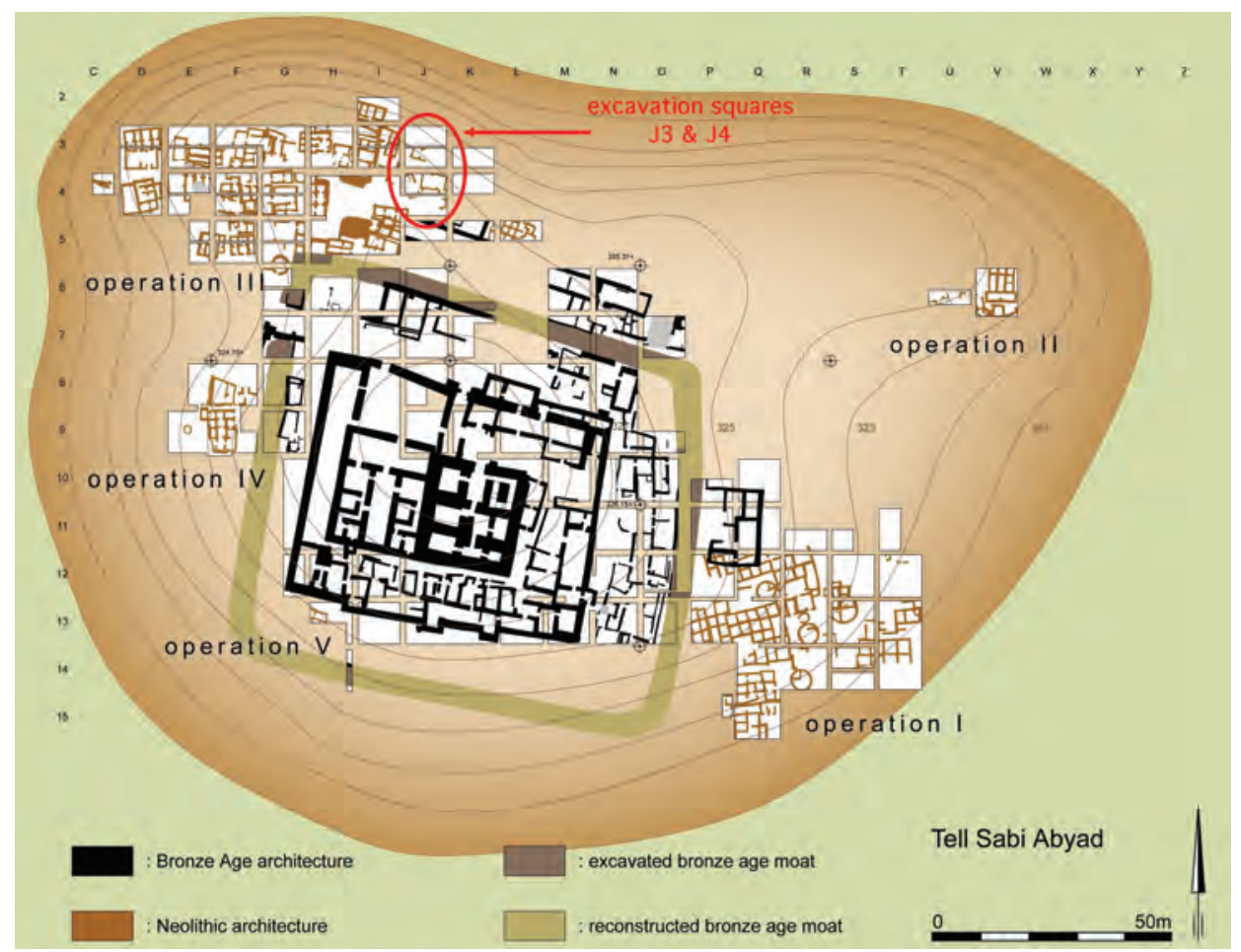

Figure 4 Schematic overview of Tell Sabi Abyad, showing the excavations of Operation III and the excavation squares $\mathrm{J} 3$ and $\mathrm{J} 4$ discussed in this paper.

sociated with structures during their use, but rather are located in open areas or dug into structures after abandonment.

In the squares studied thus far, seven periods of funerary use of the area could be distinguished, most of which are separated by the shifting habitation patterns also witnessed elsewhere on the site, or otherwise separated by level. Cemeteries 1-3 are dug from the C-sequence layers, Cemeteries 4-6 from the B-sequence layers and Cemetery 7 from the A-sequence layers. It is likely that the eventual stratigraphic analysis of the graves in the remaining squares will alter this division of cemeteries.

\section{Cemetery 1}

Cemetery 1 is the youngest burial phase and includes 14 graves younger than or contemporaneous with a number of characteristic round structures (so-called tholoi, singular: tholos) and ovens found in squares $\mathrm{J} 3$ and $\mathrm{J} 4$, belonging to levels $\mathrm{C} 5$ and $\mathrm{C} 4$. Prior to the construction of these structures, a large part of the slope was dug away, creating a horizontal terrace. These terracing activities cut into the earlier C-sequence layers and even into the late B-sequence layers. Therefore, the graves directly under the tholos phase are from various different periods in the use of the cemetery. The graves comprising Cemetery 1 are BN07-34, BN07-36, BN07-52, BN07-102, BN07-110, BN07111, BN08-4, BN08-5, BN08-6, BN08-10, BN08-18, BN08-24, BN08-45, and BN08-67. Of all the graves of Cemetery 1 , only BN07-102 and BN07-52 could be dated successfully using ${ }^{14} \mathrm{C}$.

\section{Cemetery 2}

The five Cemetery 2 graves-BN07-118, BN08-32, BN08-36, BN08-37, and BN08-58 - are from the layers older than the level $\mathrm{C} 4-\mathrm{C} 5$ structures in $\mathrm{J} 4$ and $\mathrm{J} 3$, and younger than a series of SW-NE 
oriented walls under the tholos phase, built against the slope of the mound and belonging to level C8. Most likely, the series of walls was built to support a platform. The collagen of the bones from the Cemetery 2 graves were so degenerated that no successful carbon dating could be achieved on these remains.

\section{Cemetery 3}

The Cemetery 3 graves are those found in, or dug from, the thick deposit of C-layers (level C9) laying directly on top of the B-sequence. The layers are partially underneath the platform walls, and partly under the tholos phase. No architecture in squares J3 and J4 is associated with these deposition layers. Perhaps these layers, which contain mainly Halaf with some Transitional pottery sherds, are erosion layers, originating from an older $\mathrm{C}$-sequence occupation higher up on the mound. This cemetery includes the following 17 graves: BN07-116, BN08-28, BN08-29, BN08-30, BN0831, BN08-41, BN08-51, BN08-52, BN08-53, BN08-56, BN08-57, BN08-65, BN08-66, BN09-11, BN09-12, BN09-13, and BN09-62. Of these graves, BN08-41, BN08-29, BN08-65, BN08-56, and BN09-13 have yielded successful ${ }^{14} \mathrm{C}$ dates.

\section{Cemetery 4}

The 12 graves in Cemetery 4 are the youngest graves associated with the B-sequence. These graves (BN07-113, BN07-114, BN07-115, BN08-7, BN08-14, BN08-47 BN08-49, BN09-1, BN09-4, BN09-31, BN09-47, and BN09-53) are dug from levels B4-B6, which lay directly under the thick deposit of C-layers associated with Cemetery 3. Of this group of graves, BN07-115, BN08-49, BN07-114, BN09-1, BN09-31, BN09-47, and BN09-53 could be dated.

\section{Cemetery 5}

Ten graves belong to Cemetery 5: BN08-23, BN08-39, BN08-40, BN08-42, BN08-46, BN08-59, BN08-61, BN08-62, BN08-64, and BN09-61. All graves included in this cemetery are dug from level B7, or are at least older than level B6, and are located in the layers partially overlaying a large, red, mudbrick floor found in squares $\mathrm{J} 3, \mathrm{~J} 4, \mathrm{~K} 3$, and $\mathrm{K} 4$. Of these graves, BN08-39, BN08-40, BN08-62, and BN08-64 yielded collagen sufficiently well preserved to be dated.

\section{Cemetery 6}

The 10 graves of Cemetery 6 are dug from the oldest B-sequence layers (levels B8 and B9). This cemetery includes graves BN08-60, BN09-10, BN09-14, BN09-25, BN09-26, BN09-37, BN09-38, BN09-46, BN09-50, and BN09-51. These B-sequence layers were cut during terracing activities prior to the construction of the red mudbrick floor, and only partially underlay the floor. These layers lie directly on top of the A-sequence layers that show evidence of considerable erosion. Graves BN08-60, BN09-10, BN09-14, BN09-25, BN09-37, and BN09-38 were dated successfully. BN0910 was found in the same layer as BN09-37 and BN09-38, but further up the slope of the mound, and is dug into a part of the A-sequence that has suffered significant erosion. Consequently, it is located in the proximity of a cluster of Cemetery 7 graves. However, its ${ }^{14} \mathrm{C}$ date differs greatly from those of these graves, and thus points to a Cemetery 6 origin. BN09-14 is located on the border between the A- and B-sequence, and is most likely dug from level $\mathrm{B} 8$, regarding the average burial pit depth of a meter usually recorded on the site. BN09-25 has a similar context, but is found just under the surface of the A-sequence. The ${ }^{14} \mathrm{C}$ dates of these two graves also correspond to a placement in Cemetery 6 .

\section{Cemetery 7}

The Cemetery 7 burials are located in the layers of the oldest habitation sequence of the site, se- 
quence A. This cemetery includes 18 graves: BN08-50, BN08-54, BN08-63, BN08-68, BN08-69, BN09-2, BN09-3, BN09-8, BN09-9, BN09-19, BN09-21, BN09-23, BN09-27, BN09-28, BN0929, BN09-33, BN09-34, and BN09-35. Of these, BN08-63, BN08-68, BN09-2, BN09-3, BN09-8, BN09-9, BN09-21, BN09-23, BN09-27, BN09-2, BN09-34, and BN09-35 have been dated successfully.

BN09-3 is located about $30 \mathrm{~cm}$ under the surface of the A-sequence. Considering its location and lack of visible burial pit, it could have also been a Cemetery 6 burial; however, the ${ }^{14} \mathrm{C}$ date is one of the oldest dates of all graves under study, and much older than those from Cemetery 6. Moreover, the sections show evidence of erosion in this area; the original pit depth was most likely greater. Therefore, it seems safe to include this burial in Cemetery 7.

\section{RADIOCARBON DATING: SELECTION AND PRESERVATION ISSUES}

A total of 246 human bone samples were selected for isotopic analysis. Bone collagen was prepared following an improved version of the Longin method (Longin 1971; Mook and Streurman 1983). The ${ }^{14} \mathrm{C}$ measurements were performed at the Groningen AMS facility (van der Plicht et al. 2000).

The following criteria were used to assess the preservation of the collagen. The $\mathrm{C}: \mathrm{N}$ atomic ratio was calculated (C/N \% multiplied by 14/12). The accepted range of atomic C:N values for well-preserved prehistoric specimens is 2.9-3.6 (DeNiro 1985). Values outside this range may have suffered diagenic alteration causing changes to the organic composition. Also, as a general rule, the carbon content of the collagen (C\%) should be $\sim 30-45 \%$ and the nitrogen content $(\mathrm{N} \%)$ around $11-16 \%$ for the results to be reliable, although sometimes lower values appear acceptable for dating (e.g. Rutgers et al. 2009). For the ${ }^{14} \mathrm{C}$ dating, samples with acceptable $\mathrm{C} \%$ values were also accepted, when no $\mathrm{N}$ analysis (and thus no $\mathrm{C} / \mathrm{N}$ ratio) is available, mainly due to the small sample size.

The collagen from Tell Sabi Abyad bone material was generally not well preserved, and many samples failed or did not meet high enough collagen yields to be considered reliable. As mentioned above, we concentrated on the squares J3 and J4 (Figure 4), which represent 92 individual graves that yielded 46 bones with acceptable quality for ${ }^{14} \mathrm{C}$ dating. These dates are analyzed by applying Bayesian statistics. It is worth noting that the three youngest cemeteries $(1,2$, and 3$)$ have a far lesser preservation of the collagen compared with the other cemeteries. Cemetery 2, for example, yielded no successful ${ }^{14} \mathrm{C}$ dates.

The vast majority of the ${ }^{14} \mathrm{C}$ analysis results show $\mathrm{C} \%, \mathrm{~N} \%$, and $\mathrm{C} / \mathrm{N}$ values falling within the ranges considered acceptable, as discussed above. For six samples, no $\mathrm{N}$ values are available; due to the very small sample size, only $\mathrm{C}$ could be analyzed. For these, the $\mathrm{C}$ content $(\mathrm{C} \%)$ of the collagen is well within acceptable range; thus, these dates are included in our Bayesian analysis. For four samples, the $\mathrm{N} \%$ and/or $\mathrm{C} / \mathrm{N}$ ratio is outside the range. We would not use these for interpretations based on ${ }^{15} \mathrm{~N}$. The $\mathrm{C} \%$ value is around $30 \%$, which we consider acceptable concerning the ${ }^{14} \mathrm{C}$ date.

In an earlier study, a large sample of faunal bones was analyzed for the stable isotopes ${ }^{13} \mathrm{C}$ and ${ }^{15} \mathrm{~N}$ (Russell 2010). The collagen quality success rate of these faunal samples was $\sim 30 \%$, similar to what we observe for the human bones. The low collagen success rate is very likely the result of the arid conditions of the region, which can lead to collagen destruction shortly after burial (Bocherens et al. 2000; van Klinken 1999). Isotope studies on material from Anatolia have revealed similar problems with collagen preservation (e.g. Richards et al. 2003). Nevertheless, regarding the age of the sample, i.e. $\sim 8000 \mathrm{yr}$ old, the yield obtained may be considered quite reasonable. 


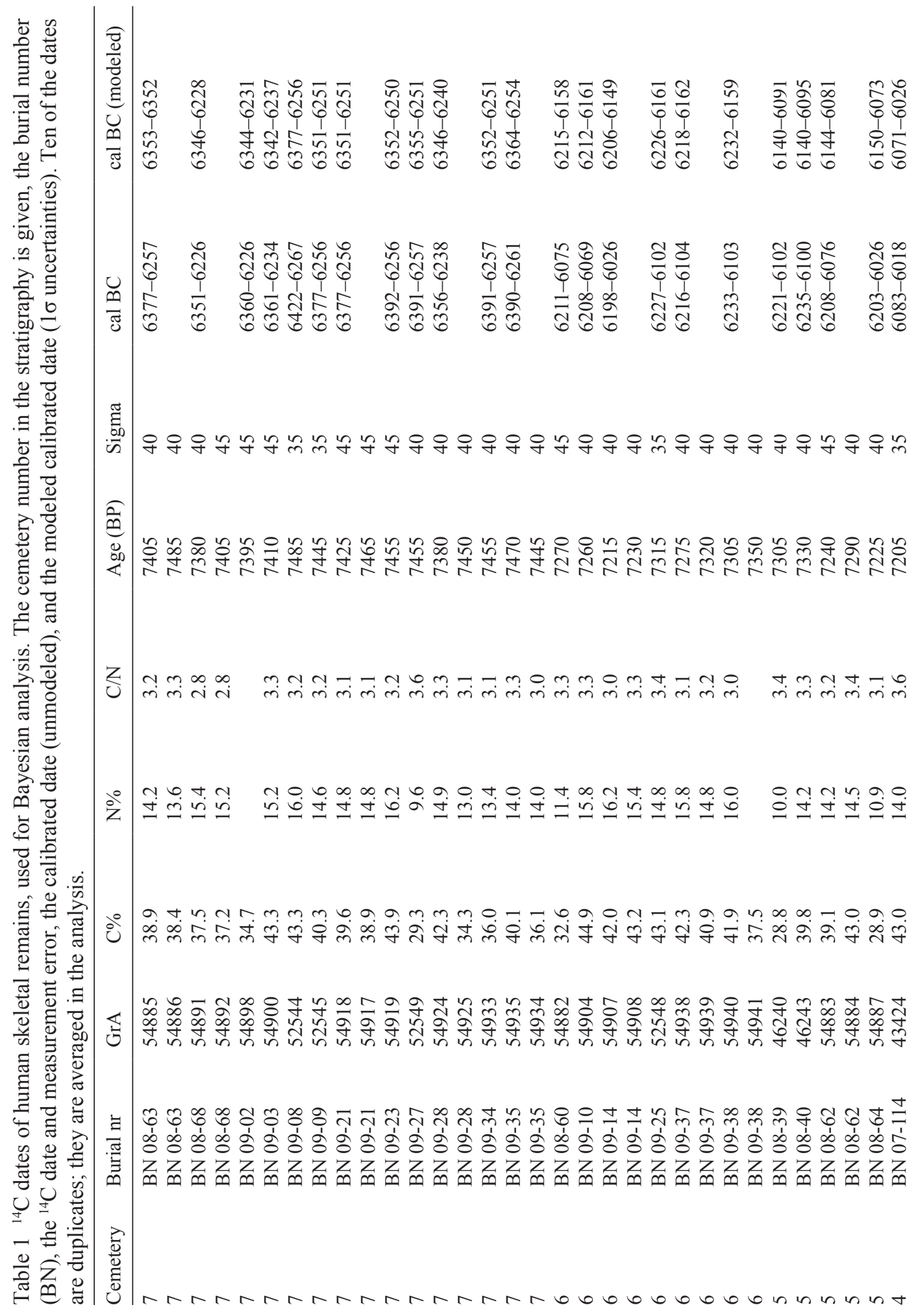



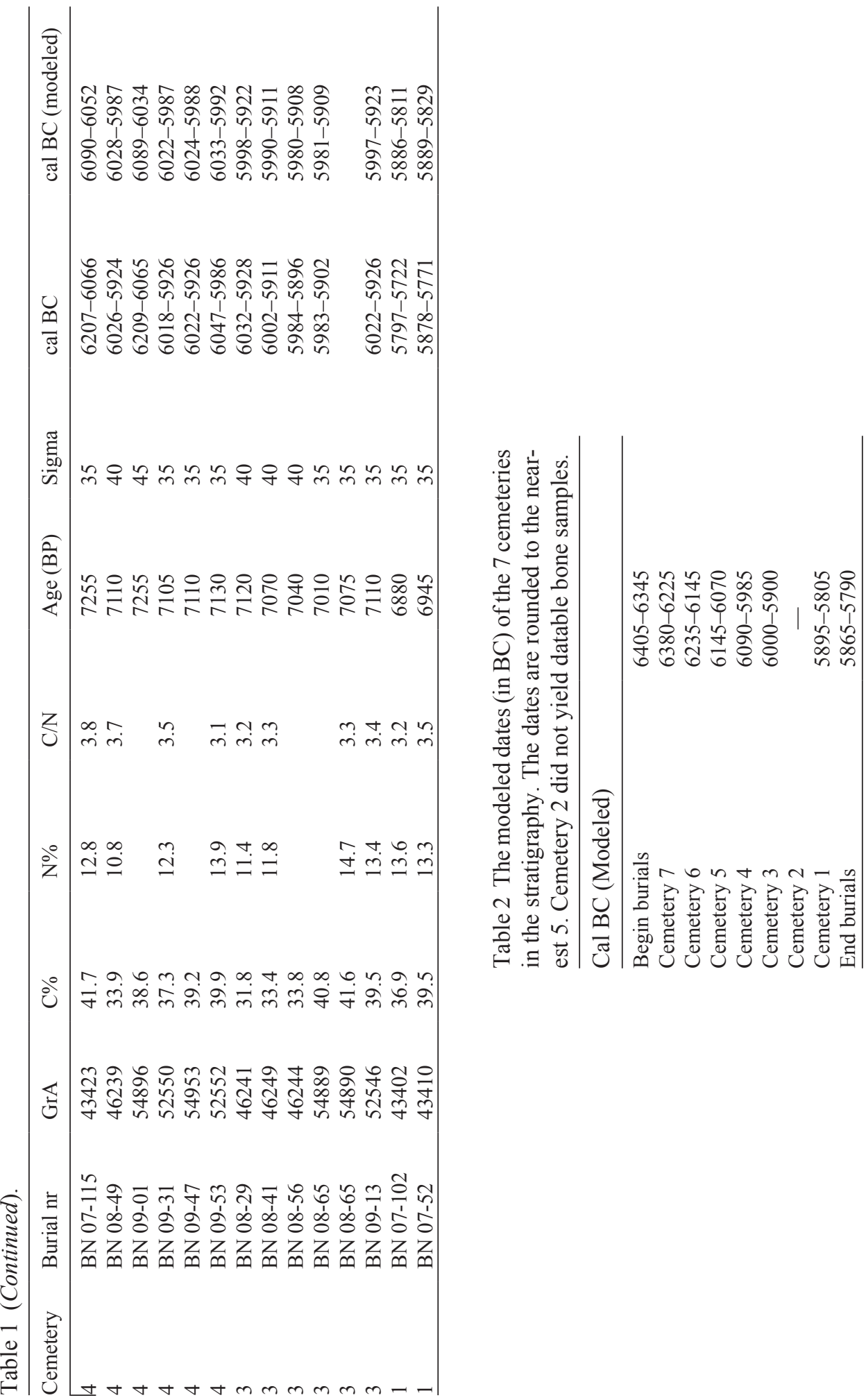

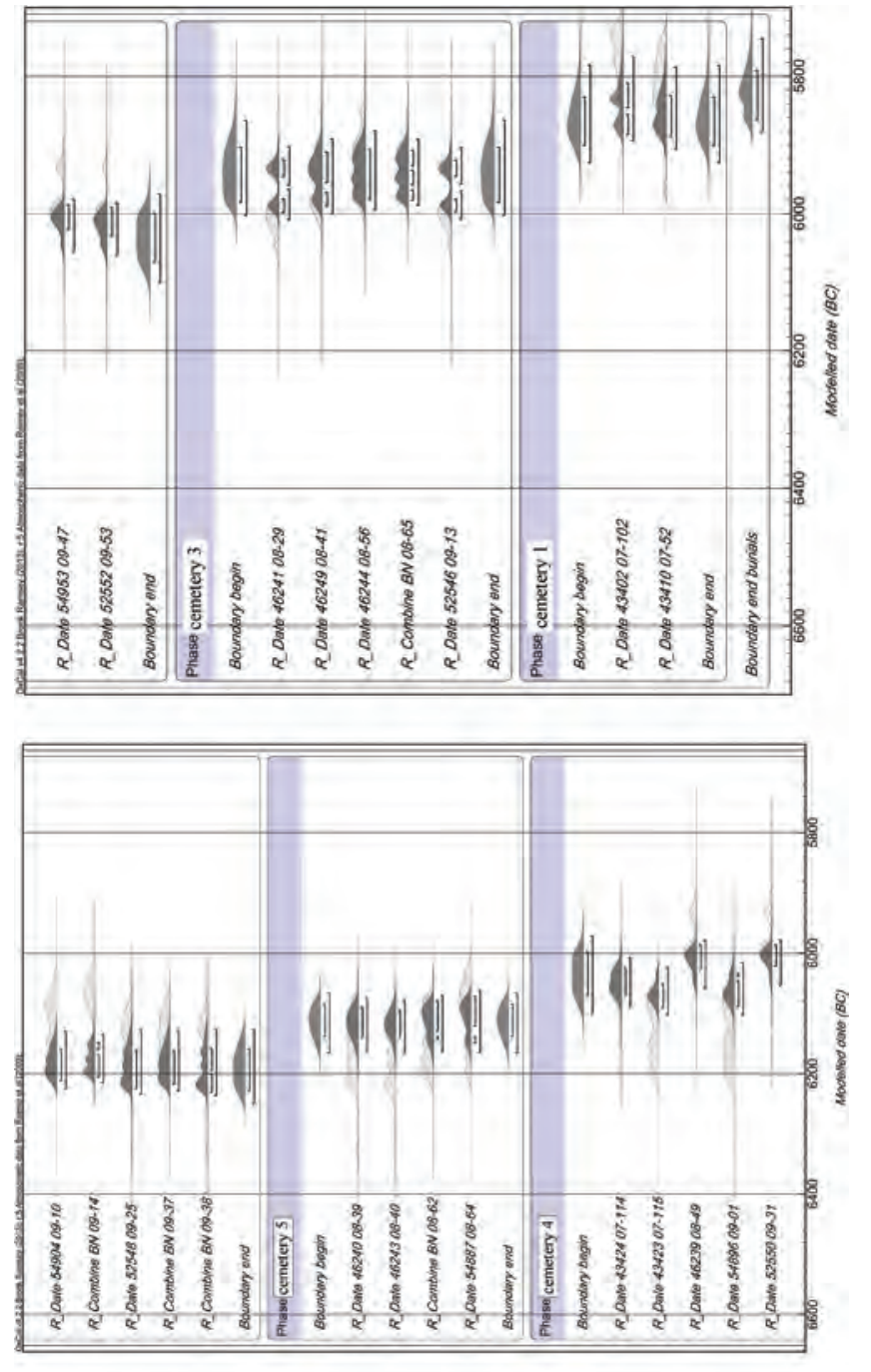

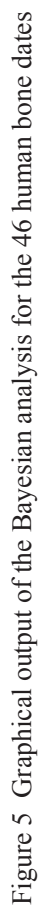


The accepted measurement results are shown in Table 1 . The table shows cemetery number, burial number, GrA number, and for each the ${ }^{14} \mathrm{C}$ date and calibrated date range $(1 \sigma)$. The ${ }^{14} \mathrm{C}$ dates are reported as conventional dates in BP, i.e. they are determined relative to the oxalic acid standard, calculated using the Libby half-life and corrected for isotopic fractionation (Mook and Streurman 1983). All numbers are rounded to the nearest 5 .

\section{BAYESIAN ANALYSIS}

In the timeframe of interest here, calibration of individual ${ }^{14} \mathrm{C}$ dates yield complex and broad probability distributions. Consequently, the temporal resolution on the calendar timescale is not good enough to derive a precise chronological inference. The temporal resolution can be significantly improved by applying additional information to the ${ }^{14} \mathrm{C}$ dates, using Bayesian statistics. This enables calibrated ${ }^{14} \mathrm{C}$ ages to be included along with their relative archaeological stratigraphy (Bayliss 2009; Bronk Ramsey 2009). Only good quality data should be selected, from both the ${ }^{14} \mathrm{C}$ laboratory point of view, as well as archaeological point of view (van der Plicht et al. 2009).

Six of the seven cemeteries from squares J3/J4 yielded datable bones from graves with good archaeological contexts, i.e. fulfilling the stringent requirements for Bayesian analysis (e.g. Bayliss 2009) as far as possible. As elaborated upon above, of the 92 graves found in squares $\mathrm{J} 3$ and $\mathrm{J} 4$, seven were excluded on the basis of stratigraphical uncertainty, and 39 on the basis of quality requirements for ${ }^{14} \mathrm{C}$ dates, leaving 46 dates (from 36 individual graves) for the Bayesian analysis: two for Cemetery 1 , none for Cemetery 2 , six for Cemetery 3 , seven for Cemetery 4 , five for Cemetery 5 , nine for Cemetery 6, and 17 for Cemetery 7.

Bayesian analysis of the sequence of cemeteries was performed using the OxCal v 4.2 program (Bronk Ramsey 2009) and the IntCal09 calibration curve (Reimer et al. 2009). The dates were grouped per cemetery, and results are shown in Figure 5. A few duplicate samples are combined, as indicated. The figure shows the calibrated (Bayesian modeled) ages for the human graves for each phase. It shows a good, consistent, and continuous age distribution between 6400 and $5800 \mathrm{BC}$. This means that the chronology of the graves is understood in the archaeological sense, and that the modeled ${ }^{14} \mathrm{C}$ dates provide the absolute timescale of this unique burial site. The resulting numbers are summarized in Tables 1 and 2. Table 1 shows the calibrated date ranges $(1 \sigma$ level $)$ in $\mathrm{BC}$ calculated by $\mathrm{OxCal}$, both for the single dates as well as for the modeled results. The significance index A of our model is $\mathrm{A}=80$, which is considered good. Only two dates show relatively poor agreement $(\mathrm{A}<60)$ for the fit: BN 09-14 and BN 07-102. This number of two out of a series of 46 is considered quite reasonable from a statistical point of view.

The resulting calibrated time ranges for the cemeteries are shown in Table 2 (rounded to the nearest 5). The cemetery phases are firmly dated to 5895-5805 BC (Cemetery 1), 6000-5900 BC (Cemetery 3), 6090-5985 BC (Cemetery 4), 6145-6070 BC (Cemetery 5), 6235-6145 BC (Cemetery 6), and 6380-6225 BC (Cemetery 7). The outcomes of the Bayesian analysis confirm the continuity of use of the northeastern slope of the mound as a burial ground throughout the Initial Pottery Neolithic to Halaf period.

\section{CONCLUSION}

At Tell Sabi Abyad, Syria, we obtained a robust chronology for the Late Neolithic graves found in Operation III. A picture of continuous funerary use of the northeast slope of the mound has emerged. The results reported here will be interpreted within the complete context of the Late Neolithic habitation and burial grounds at the site. This will enable the extensive study of mortuary and health 
patterns at Tell Sabi Abyad through time, and will represent the best-dated burial sequence of the Late Neolithic in the Near East.

\section{ACKNOWLEDGMENT}

The work is supported by the Netherlands Royal Academy of Sciences (KNAW) in the form of a student assistantship to the first author.

\section{REFERENCES}

Akkermans PMMG. 2008. Burying the dead in Late Neolithic Syria. In: Cordoba JM, Molist M, Perez C, Rubio I, Martinez S, editors. Proceedings of the 5th International Congress on the Archaeology of the Ancient Near East. Madrid: Universidad Autónoma of Madrid. p 621-45.

Bayliss A. 2009. Rolling out revolution: using radiocarbon dating in archaeology. Radiocarbon 51(1):123 47.

Bocherens H, Mashkour M, Billiou D. 2000. Palaeoenvironmental and archaeological implications of isotope analyses $\left({ }^{13} \mathrm{C},{ }^{15} \mathrm{~N}\right)$ from Neolithic to present in Qazvin Plain (Iran). Environmental Archaeology 5(1):1-19.

Bronk Ramsey C. 2009. Bayesian analysis of radiocarbon dates. Radiocarbon 51(1):337-60.

Croucher K. 2012. Death and Dying in the Neolithic Near East. Oxford: Oxford University Press.

DeNiro MJ. 1985. Postmortem preservation and alteration of in vivo bone collagen isotope ratios in relation to palaeodietary reconstruction. Nature 317(4040):806-9.

Longin R. 1971. New method of collagen extraction for radiocarbon dating. Nature 230(5291):241-2.

Mook WG, Streurman HJ. 1983. Physical and chemical aspects of radiocarbon dating. In: First Symposium on ${ }^{14} \mathrm{C}$ and Archaeology, Groningen. PACT 8:31-55.

Nieuwenhuyse OP, Akkermans PMMG, van der Plicht J. 2010. Not so coarse, nor always plain - the earliest pottery of Syria. Antiquity 84(323):71-85.

Reimer PJ, Baillie MGL, Bard E, Bayliss A, Beck JW, Blackwell PG, Bronk Ramsey C, Buck CE, Burr GS, Edwards RL, Friedrich M, Grootes PM, Guilderson TP, Hajdas I, Heaton TJ, Hogg AG, Hughen KA, Kaiser KF, Kromer B, McCormac FG, Manning
SW, Reimer RW, Richards DA, Southon JR, Talamo S, Turney CSM, van der Plicht J, Weyhenmeyer CE. 2009. IntCal09 and Marine09 radiocarbon age calibration curves, 0-50,000 years cal BP. Radiocarbon 51(4):1111-50

Richards MP, Pearson JA, Molleson TI, Russell N, Martin L. 2003. Stable isotope evidence of diet at Neolithic Çatalhöyük, Turkey. Journal of Archaeological Science 30(1):67-76.

Russell A. 2010. Retracing the Steppes: a zooarchaeological analysis of changing subsistence patterns in the Late Neolithic at Tell Sabi Abyad, northern Syria, 6900 to $5900 \mathrm{BC}$ [PhD thesis]. Leiden: Leiden University.

Rutgers LV, van Strydonck M, Boudin M, van der Linde C. 2009. Stable isotope data from the early Christian catacombs of ancient Rome: new insights into the dietary habits of Rome's early Christians. Journal of Archaeological Science 36(5):1127-34.

van der Plicht J, Wijma S, Aerts AT, Pertuisot MH, Meijer HAJ. 2000. Status report: the Groningen AMS facility. Nuclear Instruments and Methods in Physics Research B 172(1-4):58-65.

van der Plicht J, Bruins HJ, Nijboer AJ. 2009. The Iron Age around the Mediterranean: a High Chronology perspective from the Groningen Radiocarbon Database. Radiocarbon 51(1):213-42.

van der Plicht J, Akkermans PMMG, Nieuwenhuyse O, Kaneda A, Russell A. 2011. Tell Sabi Abyad, Syria: radiocarbon chronology, cultural change, and the 8.2ka event. Radiocarbon 53(2):229-43.

van Klinken GJ. 1999. Bone collagen quality indicators for palaeodietary and radiocarbon measurements. Journal of Archaeological Science 26(6):687-95. 